\title{
Ranajit Guha: Tribute to a Scholarly Life in Postcolonial Studies
}

The opportunity of celebrating and honouring the scholarly paths and achievements of Ranajit Guha represents not only an enormous honour to $\mathrm{me}^{1}$. It also is a challenge. This task simultaneously includes two seemingly contradictory dimensions. One of these two dimensions displays transparent simplicity, because Ranajit Guha is a world famous scholar. His towering influence throughout the past three decades upon the humanities and the social sciences at large is so obvious, that it is readily acknowledged by large parts of a global academic public. At the same time, however, the second dimension of this task includes a whole avalanche of complexity. That complexity is derived not only from the astonishing wealth, scope and range of Ranajit Guha's work and the new horizons it has opened, but also, it is related to the diversity of all the various consequences and impact effects it has had in various fields. My task with this twofold challenge of simplicity and complexity in all likelihood will yield an unfinished and incomplete result. A few paragraphs cannot possibly do justice to the life achievements of a true academic revolutionary, as I am sure everybody will understand. I thus can only hope that like a minor and prosaic parallel to Schubert's symphony no. 8, also known as the "unfinished" one or "die Unvollendete", my own incomplete efforts nevertheless will indicate at least some of the grandeur and the importance of Prof. Guha's merits and achievements.

Allow me to begin and then to also end with the simple dimension, that is, with those aspects that seem to be simple because they are so exceptional and outstanding. Prof. Guha has revolutionized not only the fields of South Asian history, but by doing so, he and his now equally famous disciples have changed the ways in which we pursue colonial and postcolonial history, and in which we approach social science studies as well in this postcolonial globalized world that we inhabit today.

In addition to a large number of scholarly articles, Prof. Guha's most famous single-authored book publications include

- A Rule of Property for Bengal. An Essay on the Idea of Permanent Settlement (1963),

- Elementary Aspects of Peasant Insurgency in Colonial India (1983),

- Dominance without Hegemony. History and Power in Colonial India (1996), and

- his most recent book, History at the Limit of World-History (2002)

(For the full references, see the list of publications at the end of both of these texts.) Prof. Guha has taught at several universities, and has received several honours and invitations in India, in Australia, in Britain, as well as here in Vi-

\footnotetext{
${ }^{1}$ I would like to acknowledge the anonymous reviewer's helpful comments, and also, the assistance of Dr. Maria Six-Hohenbalken in providing some of the materials that helped me to prepare this text. Ranajit Guha and I also wish to express our gratitude to her, to Verena Loidl (both Institute for Social Anthropology at the Austrian Academy of Sciences) and to the Austrian Academy of Sciences' Vice President until 2009, Prof. Herbert Matis, for initiating and preparing the public event of November 2008 that preceded the publication of these texts.
} 
enna, where we are happy to now also host him as a resident with his Austrian wife, who studied at our Vienna anthropology department.

Beyond his book publications, and perhaps equally influential and well known is Prof. Guha's role as the founder, and as the editor of the first six volumes of "Subaltern Studies" - the book series that in fact represented a whole scholarly movement founded and inspired by Prof. Guha's efforts and initiatives. Contributors and editors of that series comprised a whole range of now famous scholars such as Dipesh Chakrabarty, Partha Chaterjee, Gyandra Pandey, Gayatri Chakravorty Spivak, and many others. In this way, his authored and edited work testify to Ranajit Guha's role as a true pioneer for what now is called postcolonial studies and represents a cross-cutting, inter- if not transdisciplinary research field. A scholar's aspirations always live on in his own works as much as in the activities of his disciples. If you only take these two criteria, i.e. the impact of his writings and the relevance of his junior associates: then you already may get a sense of the far-reaching and substantial repercussions of Prof. Guha's achievements for the development of the humanities and the social sciences at large.

Allow me to now tease out just a few among the more complex elements in Ranajit Guha's scholarly achievements. I shall confine myself to merely three of them.

First, the term "subaltern" itself: many have criticized it, and many have tried to deconstruct it in the sense of questioning its critical potential, its practical usefulness or its empirical validity. Basically, the notion of the subaltern designates those large segments of a society's population that are defined by their oppositional relation to the forces occupying hegemonic positions of power. This, therefore, is a relational concept which intrinsically is linked to concepts of hegemonic powers in colonial or postcolonial contexts. Against its critics, Ranajit Guha always has maintained that it has to depend on concrete historical and socio-political contexts and on their analysis, in how far a specific group or a certain stratum of society does or does not fall under this category. From the outset, this position has closely tied this critical concept to open research procedures, while protecting it from the dangers of dogma. Others have argued that actually, the subaltern approach to history has much in common with what in continental and northern Europe has been labeled as "history from below". On a thematic and empirical level, that may in fact often be the case in so far as both approaches often seem to be dealing with similar types of sources and of their interpretation, and with similar social groups to which these sources relate. Still, I would argue that "history from below" approaches often rely on a somewhat more vague and somewhat more sociological notion of the "lower strata of society", while the concept of the subaltern basically is not a sociological concept. Instead, it is rooted in the political economy of hierarchical relations of power and violence. Moreover, this historically situated and relational political economy concept is comparative in the sense that its epistemological basis transcends locally bounded limits of cognition. Originally developed out of Guha's path-breaking early peasant studies, he and his many co-authors, associates, and students have shown how the concept may creatively be put to work for such different groups as poor peasants, urban middle classes, textile workers, marginalized tribal groups or popular intellectuals.

This leads me to the second key element that I would like to briefly discuss here, namely the state.

It is no coincidence that Prof. Guha began to assemble that group of junior scholars for what was to become the subaltern studies group during the 1970s, 
that is, during a particular juncture in the history of modern India. This was a time when under the leadership of the Congress Party, India's domestic situation and its international alliance with the Soviet Union had led to moments of stagnation and crisis. By consequence, this exposed precisely those two schools of thought to increased intellectual critique which corresponded to these two political forces, namely the two intellectual schools of secular nationalism and of orthodox Marxism.

Ranajit Guha's subaltern research orientation implied a radical reorientation which allowed complete intellectual independence from both of these two schools. Orthodox Marxism had implied a specific vision of a Eurocentric, industrialized modernity with a priority for urban development, and secular nationalism of course implied an endorsement of national state power without qualifications. By contrast, the subaltern approach provided a fresh start that allowed a new focus on those who actually were opposed to the respective forces of hegemonic state power in a global as well as in a local sense. Not only was this a fundamental conceptual shift towards inspirations ranging from Antonio Gramsci and Michel Foucault to a wide range of other philosophical influences. It also implied a new methodological scrutiny on sources and on their interpretation. That conceptual shift allowed unprecedented perspectives on crucial periods of colonial history as much as on the postcolonial era. Moreover, in the context of South Asia it also allowed a new assessment of what has been called partition historiography, that is, of the very painful aspects in the partition of the former British colony into the independent states of India and Pakistan in 1948. To this day, this includes dimensions that are not easy to be dealt with. It does belong to the important lessons we all were privileged to learn from Ranajit Guha that it takes acute, critical intellectual independence in order to adequately assess the painful chapters of the past if we want to benefit from that for the present.

The third key element that I think is crucial to understand the impact of Prof. Guha's work is what I would like to call global interdisciplinarity. From the outset, one of the most fascinating qualities of the subaltern approach to history has been that it combined theoretical precision with an innovative kind of broad, liberal - in the best sense of the word - methodological freedom. Perhaps this is the secret key to the huge success of subaltern and postcolonial studies throughout the past three decades: a very clear and well defined strategic orientation towards a number of key research questions combined with the sweeping power of methodological interdisciplinarity which, like a fresh and invigorating spring storm, has been blowing through the humanities and the social sciences at large. The impact could be felt, seen, and identified from literary history to the history of fine arts, from social history to the history of the contemporary world, and from sociology and political sciences, last but not least, to social and cultural anthropology. Because of their long established focus on colonial history, subaltern studies under Ranajit Guha's leadership always had to insist that their kind of historical research by definition situated itself in global frames and in contexts that were larger than regional or national. And because of their long established focus on those social forces that oppose hegemonic relations of power, research under Prof. Guha's inspiration from the outset swept across the boundaries between sociology and history, and between the humanities and the social sciences.

When after the fall of the Berlin wall in 1989, a whole generation suddenly understood that something like globalization was going on, which would necessitate new transdisciplinary and transnational orientations, it became clear 
very soon that Ranajit Guha and his students had been working along these insights already for quite a while. Global, interdisciplinary and transnational approaches in fact were not a product of 1989. That year only made much more conspicuous what had been going on throughout preceding decades and centuries, as Ranajit Guha had shown. His latest book with its perspectives on world history testifies in excellent ways to this fact. The kind of postcolonial studies which he founded and continues to inspire cannot be contained to any regional level such as Asia. They are relevant for Africa, the Americas, or Europe as much as for world history.

Allow me to finish my unfinished tribute to Prof. Guha by another note of simplicity. He was born in what today is Bangla Desh, he took his degree in India, he has taught and lectured in four continents, and he has inspired generations of scholars. Would scholarship and academic expertise from India's humanities and social sciences ever have attained the same impressive global standing that they have today without him? This would be difficult to envision. Still, his modesty and his straightforwardness are proverbial, as is his unfailing curiosity in continuing to learn. I am told that even today, he remains curious about the ways farmers and peasants here In Austria manage their lives, and I know for myself that conversations with him provide fountains of inspirations for those who are as humble as he is in his ability to listen. His, indeed, is an intellectual voice to be listened to.

\section{Translating Between Cultures}

\section{RANAJIT GUHA}

\section{WritTEN FOR THE ÖSTERREICHISCHE AKADEMIE DER WisSENSCHAFTEN, 11 NOVEMBER 2008}

Ladies and Gentlemen, as I get ready to speak, I must confess to a certain trepidation. For I know that I am addressing a highly distinguished audience of social scientists. Once, as a historian, I belonged to that community myself, less perhaps as a fully paid-up subscriber than as a classificatory kin. When I graduated with a Master's degree from Calcutta University in the 1940's, history was still regarded as a classical humanist discipline in the early Renaissance sense of Humanism. Yet, it could not resist the drift that had begun with the first H-bomb and made the post-war generation of scholars believe that the universal truth of physics would be within their grasp if the study of the past were recognized as a positivist science. History became a social science, - a Faustian contract, and our discipline, once exemplary for its humanism, lost its soul. The consequences are now clear. And as we are rushing to undo the damage done, the role of the Austrian Academy of Sciences becomes obvious as an institution that promotes critical inquiry as a necessary condition for opening up and broadening the space for exchange of ideas between individuals and cultures. For it stands in a direct line of succession to the most ancient sceptical tradition of the West, namely, that of the first Academy.

It was such thoughts which were racing through my mind when I was told about the Austrian Academy of Sciences' decision to bestow this honour on my humble work done for South Asian studies, and this led me back into my own past. All I found there was an incurably disobedient child who was a constant source of irritation to the elders at home and at school. It was my incorrigible 
habit of asking why about everything that caused the irritation. This was unacceptable in the patriarchal social and cultural milieu of India in those days as a British colony. So I was always reproached as precocious by my guardians. In fact I broke so many rules that no one even bothered to ask me why I went on questioning as I did. Had they done so, I would have told them that I read somewhere in a book recommended by my grandfather, the patriarch of the family, in which there were stories about Great Men called Geniuses, and I happened to be impressed by the one about Socrates where to doubt everything was recommended as a virtue. I took this to be something well-known to the elders and just used it to show them that I too had grown up.

Thus, it happened that I simply grew up as a sceptic, and as I started on my academic career in India and then England, colleagues sometimes found my teaching to be idiosyncratic for it deviated from the syllabus, while almost always students found it stimulating. Scepticism had become so much a part of me that without being self-conscious about it I used to teach students to ask why. I remember liberally using a metaphor for my lessons to advanced students - that of fishing. If you want to catch big fish, you wouldn't find it by looking from above. It merges in the dark of the depth that is completely indistinguishable from its environment. However, if you look at the bottom you will see the underbelly of the beast shining silvery and unmistakable as a target for harpooning it. It is in honour of this sceptical tradition that we have gathered here today.

It makes me feel humble to think that the Austrian Academy of Sciences has thought it fit to find a place for South Asian studies and the project Subaltern Studies in this tradition. Many individual and institutional efforts have led to this development. So far as I am concerned, it all seems to have begun with a thesis I wrote in 1953. I was still an economic historian by profession and had started to write a thesis about a land law in what was British India, and yet as I sat down to write it, the title came out as The Idea of Permanent Settlement. To my friends this was no surprise and they said - Ah! So Ranajit has once again done a History of Ideas exercise, hasn't he always been a bit like that. Well, by that time, long after Husserl and Heidegger, phenomenology had indeed established itself as a powerful subject on the European academic scene, and gradually together with all the others in a similar situation, I too found my work classified as History of Ideas. The question of the subject's autonomy in the knowledge system had obviously established itself in academic-historical discourse well enough to testify to its duplexities, its classical birthmark.

A birthmark, we know since Aeschylus and Oedipus Rex, is the most unmistakable sign of identity. This is precisely what made social anthropology (ethnology) so exciting to the great social scientists of our time from Bronislav Malinowski to Claude Lévi-Strauss. Both have defined the parameters of this realm of knowledge in such a way that their writings are of seminal importance, and if I had any say in the matter at all, I would have recommended the former's The Coral Islands and the latter's Social Ethnography as texts for advanced work in my discipline, for these are, in my view, truly ur-texts.

A birthmark is always and necessarily evidence of duplexity. This is as true of social anthropology as of History itself. For, to be duplex is to anticipate the question - duplex or ambiguous about what. As in the case of all anticipation, the meaning of the question is implicit in that of the 'what', which clearly belongs to the realm of possibility. Just as the subject is already implicit in the yet in-complete meaning of a sentence before its completion, duplexity of meaning too bears in cell-form the possibility of completeness. Thus duplexity works 
with meaning as it waits for its Other - that is, Death itself where alone man meets his Destiny, the ultimate Other beyond which there is no knowing the Self. For as Freud had so wisely named it, no one could know himself or herself better than Oedipus as the King whose sense of public duty proved stronger than parental obligation or than Antigone whose sense of community defied patriarchy.

With this, I think, we have come to Bronislav Malinowski. For his life is truly an Oedipian text where fate makes of man an object of pure contingency without his knowledge. Malinowski's career is arguably that of the foremost social scientist of the 20th century. Yet, he is a rebel: he had a score to settle with patriarchy and was forced by circumstance to assert it by openly choosing the sense of the place or community where alone he thought his loyalty belonged.

All this happened contingently indeed. For no good reason that can explain it, Malinowski found himself exiled in a land the British Government of the day considered most reliable for the security of its empire - a group of Pacific islands which had grown into a colony inhabited by the Trobriand people. His crime was that he had the wrong sort of name. Academically speaking, he could not have been more British and was in fact teaching social anthropology at the London School of Economics with his very first work recognized by all as a major contribution to the subject itself. However, as the First World War broke out Malinowski came to be regarded, by definition, as an alien. So he had to be exiled to a land identified with England's arch enemy Germany, but exiled in such a manner that his work could still be displayed as a continuation of his studies on the Coral Islands and their place in the tradition of the islanders themselves.

Although his name fell foul by British ears, for Bronislav Malinowski himself it was, to the contrary, his Balkanesque name that made him proud enough to seek displacement precisely into the niche where he belonged by virtue of the sheer originality of his researches. One does not have to go too far to seek a close parallelism here in yet another Balkanesque orientation, namely, that in the work of Joseph Conrad. An alien, again, by British imperial definition, Conrad too would assert his identity proudly as he made a place for himself in an ongoing story. This was done, of course, in the role of Marlow, ready to take over the narrative even from the formidable Mister Kurtz, and tell the reader, as in the Heart of Darkness, one or two things he had seen or heard himself. He had indeed penetrated the Heart of Darkness and heard the drums roll at a distance in the night, and as the boat cleared the bush he saw the Queen of Darkness herself.

It is precisely at this twilight zone that Science met Empire. And the Coral Gardens and their magic belonged right there - and it's we the readers who have everything to gain from this encounter. We are the beneficiaries primarily because, it is a fully self-conscious work, if there was one, as a model of science never failing to watch and check every step taken and constantly revising itself. The result, curiously enough, is not merely that one has the most authentic field-work data to rely on, but that the information so gathered, checked, filtered and corrected over and over again, seems always to come up with new suggestions at every reading.

Let me illustrate with an experience entirely my own. As one interested in magic, I had turned once again to the magnificent overview of his 'Early Work and Inaugurative Magic' in the Gardens of Omarakana. For brevity's sake, I had itemized only a few topics on magic but my concern had always been the Urigubu prestation without which the critical questions raised in Section 2 (pp. 
196-210) regarding "Hunger, Love and Vanity as Driving Forces in the Trobriand Harvest Gift" could not be answered. What followed, for an answer, was a long and closely argued chapter on the complex structure of Trobriand society. This enables the reader to understand why a purely detached sociological view of gift and exchange leads nowhere, and why sentiments of lineage, vanity and attachment act as powerful personal motives for the urigubu gift and 'Why the urigubu cannot be a commercial transaction. - Why urigubu contributes to the stability of marriage. - How urigubu contributes to political organisation.' The words are the author's and I cite them to demonstrate not only that a vast and lucid insight into Trobriand society makes them so authentic, but that Malinowski's own observations as those of the European sociologist's are by no means what the Trobriand islander himself thinks of the urigubu.

Caught in this scintillating review in which the self-questioning irony of the professional academic approach shows up for what it is against the wisdom and experience of the Coral Islanders themselves, there's little one can do except to reflect again on the necessary duplexity of ethnography that we have already mentioned. The topics I had carefully picked out on magic now shine in their grandeur to reveal not only the gaps and omissions between "The Method of Field-work and the Invisible Facts of Native Law and Economics" (Ch. XI). They confirm, furthermore, the wisdom of Sections \#2\&3 of that chapter. Described as "An Anthropological Experiment in Detection (pp. 320-324). A challenge to the reader - The chaos of unorganized facts. - An Autobiography of mistakes...", it is followed up by the no less tell-tale title, "An Odyssey of Blunders in Field-Work" (pp. 324-330).

Confronted with this fiercely self-critical spirit, my petty academic worries about what the natives said themselves as against what they were reported to have said, and similar field-work tittle-tattle were stunned into silence. But thanks to the friendship and generosity of the chief Magician-Gardener I was invited, as a reader, to two unforgettable occasions. In both, man is witness to the slow stirring up of nature as it gets ready to give birth to a new life in the garden. I cite in extenso the choral lines (Formula 5), repetitious as they are -

The belly of my garden lifts,

The belly of my garden rises,

The belly of my garden reclines,

The belly of my garden grows to the size of bush-hen's nest,

The belly of my garden grows like an ant-hill,

The belly of my garden rises and is bowed down,

The belly of my garden rises like the iron-wood palm,

The belly of my garden lies down,

The belly of my garden swells,

The belly of my garden swells as with a child.

As the magician explains, this is the positive spell that will ensure the growth of the gardens throughout the year. However, the ceremony is not at an end yet. To complete it, it requires a spell (Formula 6) as he utters:

I strike thee, O soil, open thou up and let the crops through the ground.

Shake, $O$ soil, swell out, $O$ soil, swell out as with a child, $O$ soil.

Before passing on, let's stay with this scenario for a moment. For with Malinowski, one of the most sophisticated social scientists of his age, we have here a ringside view of an entirely new world being born. The garden, lying inert with all the rot and decay of winter in its belly, is at last waking up to the first stirrings of spring. Something akin to a human childbirth suggests the slow 
lifting, rising, reclining, growing of 'The belly of my garden', as the Magician proudly but yet so cautiously observes. Its gentle movements rise and fall sometime like an ant-hill, sometime like an iron-wood palm, but always swelling with the advent of a life -

The belly of my garden swells,

The belly of my garden swells as with a child.

It is well known that man and nature always speak each other's rhetoric, for as Nietzsche says, we can hardly speak in anything but rhetoric. On this occasion, we are doing so at the advent of a new life on earth - swell out, $O$ soil, swell out, $O$ soil, swell out with a child. The spectacle stops us in our track. Not that it is unusual for a human birth and a natural birth to occur at about the same time. However, it is rarely that the two phenomena would join together to translate the wonder of each to the other, as they seem to be doing here. To translate? The word comes easily to mind on this occasion, for the author's reputation as a linguist is no less formidable than his achievement as a social scientist. In fact, it is precisely the question of translation that occupies him most in his book Coral Gardens and their Magic, vol. II: 'The Language of Magic and Gardening'.

Crudely stated, the problem discussed there is all about a digging-stick. But Malinowski is not happy to call it so. For, that would, in his view, leave out its rich and allusive connotations. Listed by him as an implement used in gardening (pp. 132-133), it is dayma which could pass as any stick, short or long, used for digging the soil. It is, thus, functional rather than formal, in the sense that the emphasis is on use and not on shape. To paraphrase it in his own words, Dayma is a generic term for any digging implement. Graves and trenches to drain off the water when a village is flooded, and holes for laying the foundations of a residential house or yam-house are all dug with the dayma. Thus the word dayma means 'digging-stick' and not simply 'garden digging-stick'. But the use made of the dayma in the gardens is much more important than that of any other gardening tool. Therefore, according to him, the word dayma brings the gardening context immediately to the mind of the native.

What this description highlights is precisely the ubiquity of the term and its generic use. Indeed, it is not possible for the native gardener to think of his day's work without the many uses made of this word. Malinowski acknowledges this of course, and that is where his dilemma lies. For the dayma is not just any digging-stick. To think of it as such, in English, would be to wrench it out of its semantic orbit for the native as a word that is simply untranslatable with all the multiple meanings implied in its ancestral, ritual, and technical functions.

The story of the Trobriand digging-stick could have been brought to a happy ending here, but as a tribute to the master whose implacable revisionism would not spare even his own self-questioning solutions, it must be said that the problem of translatability he so brilliantly formulated, has stood the test of time as a paradox. He wants to highlight and maintain the specificity of the dayma, because it is an ancient and inalienable tradition. Which is indeed why the word circulates so easily in the native language. From the routine household chore to sombre ancestral oblations, it is common currency for the islanders' social and political exchange and requires no effort to translate as tradition. However, as already noticed, it is also untranslatable, precisely because of its ubiquitous, everyday use. Thus, we have both the specificity that translates as tradition; and the unique that is untranslatable as the quotidian and ubiquitous. 
This paradox may serve perhaps as a fitting conclusion to what we have to say on this occasion. For, translation, in its proper sense, might have had something to do with the founders of the Akademie in the way they set it up. It shows that a paradox that has room enough for self-critical questioning is precisely where translation must feel at ease with both sides of an equation eager to act as each other's substitute. As one who could be associated with the Akademie mainly because he translates between continents and cultures, I feel privileged to pay homage to that openness which is home to us all.

\section{Academic Publications}

\section{BOOKS}

West Bengal District Records: Burdwan Letters Issued 1788-1800. [Ed. with A. Mitra] Calcutta: West Bengal Govt. Press, 1956; lv +600 p.

A Rule of Property for Bengal. An Essay on the Idea of Permanent Settlement. $1^{\text {st }}$ ed. Paris \& The Hague: Ecole Pratique des Hautes Etudes, 1963; 222 p.

$2^{\text {nd }}$ ed. Orient Longman, New Delhi, 1982; Third edition: introduction by Amartya Sen. Durham, North Carolina: Duke University Press, 1996.

(Ed.) Subaltern Studies I. Writings on South Asian History and Society. Delhi: Oxford University Press, 1982; $\mathrm{x}+241 \mathrm{p}$.

Elementary Aspects of Peasant Insurgency in Colonial India. Delhi: Oxford University Press, 1983; xii + 361 p. $2^{\text {nd }}$ ed. Introduction by James Scott. Durham, North Carolina: Duke University Press, 1999.

(Ed.) Subaltern Studies II. Writings on South Asian History and Society. Delhi: Oxford University Press, 1983; xi + 358 p.

(Ed.) Subaltern Studies III. Writings on South Asian History and Society. Delhi: Oxford University Press, 1984; xi + 327 p.

(Ed.) Subaltern Studies IV. Writings on South Asian History and Society. Delhi: Oxford University Press, 1985; xi + 383 p.

(Ed.) Subaltern Studies V. Writings on South Asian History and Society. Delhi: Oxford University Press, 1987; $\mathrm{x}+296 \mathrm{p}$.

An Indian Historiography of India: A Nineteenth-century Agenda and Its Implications (Deuskar Lectures). Calcutta, Centre for the Study of the Social Sciences, 1988; 74 p.

Selected Subaltern Studies. [Ed. with G.C. Spivak] New York \& Oxford: Oxford University Press, 1988; xii + 434 p.

A Disciplinary Aspect of Indian Nationalism. Santa Cruz: Merrill Publications, University of California, 1989; ii + 40 p.

(Ed.) Subaltern Studies VI. Writings on South Asian History and Society. Delhi: Oxford University Press, 1989; $\mathrm{x}+335 \mathrm{p}$.

A Construction of Humanism in Colonial India (The Wertheim Lecture 1993). Amsterdam: Centre for Asian Studies, University of Amsterdam, 1993; 15 p.

Dominance Without Hegemony : History and Power in Colonial India. Cambridge, Mass. \& London: Harvard University Press, 1997; ix + 245 p.

(Ed.) A Subaltern Studies Reader 1986-1995. Minneapolis \& London: University of Minnesota Press, 1997; xxii + 303 p.

History at the Limit of World-History. New York: Columbia University Press, 2002; x +116 p.

Kabir Naam O Sarvanaam [A Treatise on the Problem of the Self in Poetry]. Kolkata: Talpata, 2009; 239 p. [in Bangla]

The Small Voice of History: Collected Essays. Edited and with an introduction by Partha Chatterjee. New Delhi: Permanent Black, 2009; $x+662$ p.

\section{Published ARticles \& PAPERS ${ }^{2}$}

Teen-Age Wage-Slavery in India. The Student, no. 18-19 (Bombay, December 1947)* Banglay Macbeth ['Macbeth in Bangla'], Parichay (Calcutta, 1953) [in Bangla]*

\footnotetext{
${ }^{2}$ Starred (*) items indicate that page numbers cannot be supplied for technical reasons.
} 
Medinipurer Lavan Shilpa ['The Manufacture of Salt in Medinipur'], Itihas, vol. 5:1 (Calcutta, 1954) [in Bangla], pp. 180-91

An Administrative Blue-print of 1785, Bengal Past \& Present, vol. 74:1 (Calcutta, 1955), pp. $68-78$

Introduction to West Bengal District Records, New Series: Burdwan, letters issued 1788-1880 (Calcutta, 1956), pp. lvii-lxxxiv

Report on an Investigation of the Gauripur Raj Estate Archives, Report of the Regional Records Survey Committee for West Bengal, 1955-56 (Calcutta, 1956)*

Chirasthayi Bandobaster Sutrapat ['The Formulation of Permanent Settlement', a series of five articles]. Parichay (Calcutta, 1956-57) [in Bangla], pp. 1-19, 155-167, 222-238, 457-466, 587-594

Evidence of Some Correlations of Rents and Prices in Bihar under Early British Rule, Proceedings of the Indian Historical Records Commission, pt. II, vol. 34 (Delhi, 1958), pp. 1-14

Sir William Jones: a Study in Eighteen-Century British Attitudes to India; by S.N. Mukherjee. Cambridge South Asian Studies no.6. Cambridge U.P., 1968, South Asian Review, vol. 1:4 July (London,1968), pp. 314-15

Gandhi: a Study in Revolution; by Geoffrey Ashe. Heinemann, 1960, South Asian Review, vol. 2:2 (Jan. 1969), pp. 164-66

Interpreting the Protean Text, South Asian Review, vol. 3:1 (London, 1969), pp. 83-85

The Movement for National Freedom in India. Indian Economic and Social History Review, vol. 6:4 (Delhi, 1969), pp. 439-46

Graft, Greed and Perfidy, South Asian Review, vol. 3:3 (London, 1970), pp. 9-15

On Torture and Culture, Frontier, vol. 3: 42-43 (Calcutta, 1971), pp. 9-15

The Mahatma and the Mob: Essays on Gandhian Politics: the Rowlatt Satyagraha of 1919, South Asia, vol. 3 (Sydney, 1973), pp. 107-11

Agrarian Conditions in Northern India. Vol.1: The United Provinces under British Rule, 18601900; by Elizabeth Whitcombe. Berkeley, London, University of California Press, 1972, Journal of Peasant Studies, vol.1:4 (July 1974), pp. 534-536

Neel Darpan: the Image of a Peasant Revolt in a Liberal Mirror, Journal of Peasant Studies, vol. 2:1 (London, 1974), pp. 1-46

Panchagram (Five Villages); by Tarasankar Banerjee, transl. by Marcus F. Franda and Suhrid K. Chatterjee. Delhi, Manohar Book Service, 1973, South Asian Review, vol. 7:3 (April 1974), pp. 264-265

Indian Democracy, Long Dead Now Buried, Journal of Contemporary Asia, vol. 6:1 (London, 1976), pp. 39-53

Knowing India by its Prisons, Frontier, vol. 10:11-13 (Calcutta, 1977)*

Calcutta Diary; by Ashok Mitra. London, Frank Cass, 1976, Journal of Peasant Studies, vol. 5:4 (July 1978), pp. 525-527

On Naming a New Aspiration, Frontier, vol. 11:41 (Calcutta, 1979), pp. 12-13

Two Campaigns, Frontier, vol. 12: 8-9 (Calcutta, 1979), pp. 2-6

The Representation of Peasant Insurgency in the Literature of Bengal, Peasants in History and Literature, Symposium (Canberra: Australian Academy of the Humanities, 1981), pp. $15-26$

Using Some Indian Classics, Asian Studies Association of Australia Review, vol. 5:1, July 1981, pp. $12-13$

Nimnabarger Itihas [On the History of the Subaltern], Ekshan, no. 15:3/4 (Calcutta, 1982) [in Bangla], pp. 1-32

On Some Aspects of the Historiography of Colonial India. In Subaltern Studies I (Delhi: Oxford University Press, 1982), pp. 1-7

Writing on Peasant Insurgency: a Recent Experience, Frontier, vol. 15 (Calcutta, 1982), pp. $10-12$

Orientalist Strains in Indian Historiography, Asian Studies Association of Australia Review, vol. 6:3, 1983, pp. 2-4

Prose of Counter-Insurgency. In Subaltern Studies II (Delhi: Oxford University Press, 1983), pp. 1-42

The Career of an Anti-god in Heaven and on Earth, The Truth Unites: Essays in Tribute to Samar Sen, (Ed.) A. Mitra (Calcutta: Subarnarekha, 1985), pp. 1-25

Nationalism Reduced to ,Official Nationalism', Asian Studies Association of Australia Review, vol. 9:1, 1985, pp. 103-108

Chandra's Death. In Subaltern Studies V (Delhi: Oxford University Press, 1987), pp. 135-165 
Introduction to Bernard S. Cohn, An Anthropologist Among the Historians, and Other Essays (Delhi: Oxford University Press, 1987), pp. vii-xxvi

Shanti Nei [There's no Peace'], Anushtup, vol. 22:2/3 (Calcutta, 1988) [in Bangla], pp. 29-40

Discipline and Mobilize, In Subaltern Studies VII, (Eds.) P. Chatterjee and G. Pandey (Delhi: Oxford University Press, 1992), pp. 69-120

The Authority of Vernacular Pasts, Meanjin, vol. 51:2 (Melbourne, 1992), pp. 299-302

The Small Voice of History, In Subaltern Studies IX, (Eds.) S.Amin and D. Chakrabarty (Delhi: Oxford University Press, 1996), pp. 1-12

Not at Home in Empire, Critical Inquiry, vol. 23:3 (Chicago, 1997), pp. 482-93

A Conquest Foretold, Social Text, vol. 16:1 (Spring 1998), pp. 85-99

The Migrant’s Time, Postcolonial Studies, vol. 1:2 (Melbourne, 1998), pp. 155-60

Surya O Samaygranthi ['The Sun and the Knot of Time: a Study of Temporality in the Poetry of Jivananda Das'], Baromash (Calcutta, 1998) [in Bangla], pp. 1-8

Nationalism and the Trials of Becoming, The Oracle, vol. 24:2 (Calcutta, 2002), pp. 1-20

The Turn, Critical Inquiry, vol. 31:2 (Chicago, 2005), pp. 425-430

A Colonial City and Its Times(s), Indian Economic and Social History Review, vol. 45:3 (Delhi, 2008), pp. 329-351

Foreword to Mahabharata, Book 6: Bhisma, vol. 1 (New York: Clay Sanskrit Library, 2008), pp. $\mathrm{XV}-\mathrm{Xx}$

Vorgelegt von w. M. AndRe GingRich in der Sitzung am 13. März 2009. 
